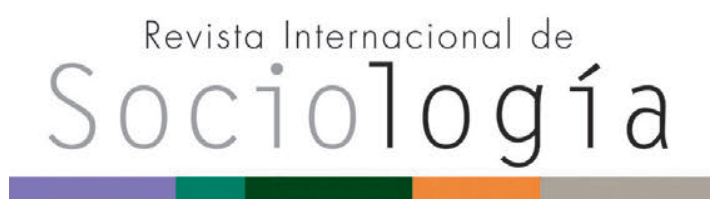

Revista Internacional de Sociología RIS vol. 74 (4), e047, octubre-diciembre, 2016, ISSN-L:0034-9712 doi: http://dx.doi.org/10.3989/ris.2016.74.4.047

\section{SOCIAL MOVEMENTS AND INTERRELATED EFFECTS: The Process of Social Change in the Post-Movement Lives of Provisional IRA Volunteers}

\author{
LORENZO BOSI \\ Scuola Normale Superiore \\ lorenzo.bosi@sns.it
}

Cómo citar este artículo / Citation: Bosi, L. 2016. "Social Movements and Interrelated Effects: The Process of Social Change in the Post-Movement Lives of Provisional IRA Volunteers". Revista Internacional de Sociología 74 (4): e047. doi: http://dx.doi.org/10.3989/ris.2016.74.4.047

\section{MOVIMIENTOS SOCIALES Y EFECTOS INTERRELACIONADOS: El proceso de cambio social en las vidas post-movimiento de los voluntarios del IRA Provisional}

Copyright: (C) 2016 CSIC. This is an open-access article distributed under the terms of the Creative Commons Attribution License (CC BY) Spain 3.0.

Received: 20/12/2015. Accepted: 01/07/2016. Published on line: 21/10/2016

\section{REsumen}

Este artículo sistematiza una perspectiva de investigación que evalúa cómo los diferentes tipos de resultados de los movimientos sociales se influyen mutuamente en el tiempo. Esto debería ofrecer una perspectiva diferente sobre las consecuencias de los movimientos sociales, cambiando el foco de atención desde los resultados individuales a procesos de cambio social generados a partir de la interacción entre diferentes tipos de efectos. La variedad de formas en las que los resultados de los movimientos se influyen potencialmente entre sí en el corto plazo, o durante un período prolongado de tiempo, se dividen en seis procesos hipotéticos. Empíricamente, a través de un enfoque centrado en los procesos, este artículo investiga cómo las respuestas políticas ofrecidas del Estado británico a la movilización disruptiva de la comunidad católica de Irlanda del Norte y la lucha armada del PIRA han dado forma a la vida post-movimiento de los voluntarios del PIRA.

\section{Palabras Clave}

Cambio a Largo Plazo; Contienda Política; Irlanda; Resultados de Movimientos Sociales.

\author{
KEYWORDS \\ Contentious Politics; Ireland; Long-term Change; Social \\ Movement Outcomes.
}


Social Movements and Interrelated Effects: The Process of Social Change in the Biographical Outcomes of Provisional IRA VolunTEERS

Would Barack Obama be sitting in the White House today if Rosa Parks had not refused to give up her seat to a white passenger on a city bus in Montgomery more than fifty years ago? While protesting is not only a matter of getting the "seats"-even if some activists seem to think so-without doubt it has its consequences. ${ }^{1}$ It is difficult to consider the election of the first African-American president of the United States without thinking of the interrelated political, cultural and biographical impacts of the mobilizations of the 1960s, and in particular the civil rights movement and the aggregate-level changes it has led to in the last half century. As Frances Fox Piven has recently written (2009), a constellation of very different factors were at play in Obama's victory (the failures of the Bush administration, the war on terrorism and especially the situation in Iraq, the economic crisis, and so forth), "[b]ut even all that would not have been enough to elect an African American as President of the United States if not for the accomplishments of the movements of the 1960s" (74). Piven then substantiates her argument by stressing how black and youth voters were determinant in Obama's election. She relates this directly to "the passage of the Voting Rights Act [1965]... ... [which] answered black demands for the right to vote and for representation as well"; and "the $26^{\text {th }}$ amendment to the constitution [which in 1971] gave the 18 - to 20 -years-olds who were at heart of [the 1960s mobilization] the right to vote" (75). What is most interesting for this article is a later passage from Frances Fox Piven, which provides an apt starting point for discussing how different movement outcomes can affect each other in the short and long term.

There is another way in which I think the Sixties movements played a role in the historic 2008 election. The Sixties movements were the spurs for the transformation of American culture, including changes in ideas and norms about sex, gender and the family, for example. ....... In the end, the Obama victory also showed that the so-called backlash to the Sixties movements was not all that was going on. In 2008 we learned that generations of people who had grown up in the cultural milieu generated by the Sixties movements, perhaps especially the popular culture of rappers and hip hop and African American sports heroes, had become if not immune at least more or less indifferent to racist appeals. (75-76)

Social movement outcomes, whether political, cultural or biographical, have been, thus far, compartmentalized into specific sub-fields within the literature on social movements and contentious politics. ${ }^{2}$ As Marco Giugni has suggested, "very little research has been done to show how a certain type of impact can help to bring about another type" (2004a: 31). By proceeding in this way, academic works have left the multiple levels of social change unconnected although they are in reality interrelated, influencing each other mutually and iteratively through long-term processes of social change. By contrast, social movement activists fully understand the relationship between different sorts of outcomes and move accordingly when choosing strategies and goals (Bernstein 2003).

Social movement impacts are not narrow paths leading from movement goals to success or failure (Bosi, Giugni and Uba 2016). Thus, we need to broaden our view of the interrelated effects of social movement outcomes, beyond their blackand-white borders, to embrace a far wider range of possibilities through which collective action affects social change, and we also need to look beyond short-term consequences to long-term changes (Sztompka 1995). A political, cultural or biographical impact may have a bearing on another type of impact, and an early consequence of such impact can give a significant boost to future broader social changes. Sometimes, however, the interrelated effects of social movement outcomes may be indirect, and delayed, even occurring well past the end of the cycle of contention that initially sparked the protest. Social movements that do not appear to be achieving their explicitly stated goals at policy level in the short term can, for example, achieve cultural effects or biographical impacts that may be fundamental to subsequent political changes, although these effects might not be visible for years. A clear example of this is the election of President Obama that was mentioned above. Here, the cultural changes prompted by the Sixties movement, and the civil rights movement in particular, had a long-term effect at a political level and contributed to the election of the first African-American president of the United States in the new millennium. On the other hand, immediate achievements may well disappear, become irrelevant in view of long-term developments, or ultimately even reverse and produce a backlash. Mobilizations not only lead to positive effects, but they can clearly do worse than failing to achieve their initial goals.

Drawing on the existing contentious literature on politics, which has not explicitly recognized the agenda of interrelated effects, the first section identifies six hypothetical processes of social change through which social movement outcomes may mutually affect each other: political $\rightarrow$ cultural, political $\rightarrow$ biographical, $\quad$ cultural $\rightarrow$ political, cultural $\rightarrow$ biographical, biographical $\rightarrow$ political, and biographical $\rightarrow$ cultural. Empirically, through a process-tracing approach focusing on the political $\rightarrow$ biographical process of social change, I will investigate how the British State's responses (policy outcomes) toward the disruptive mobiliza- 
tion of the Catholic community in Northern Ireland and to the armed campaign of the Provisional Irish Republican Army (henceforth, PIRA) have reshaped the context in which Republican politics were conducted, through voluntary and community activism for community regeneration, thus influencing the post-movement life of PIRA volunteers (biographical outcome). This empirical part draws on secondary sources and semi-structured interviews of former rank-and-file members of the PIRA. Between 2007 and 2008, I conducted 25 open-ended semi-structured interviews with rank-and-file members of the PIRA who were, at the time of my fieldwork, associated with Coiste na n-larchimí. This is an umbrella organization working for the social, economic and emotional wellbeing of current and former Republican prisoners and their families. A full description of the empirical material is available in Bosi (2012, Forthcoming). The final section of the article discusses the significance, implications and possible limitations of the interrelated effects agenda, identifying new opportunities for empirical investigations to guide future research.

\section{The Interrelated Effects: A Process- Tracing Research Strategy}

In writings on the outcomes of social movement activities, whether short-term or long-term, there have been references to the modifications at political, cultural and biographical levels and whether these are intended or unintended goals for the social movement (Giugni and Bosi 2012; Bosi and Uba 2009). Political outcomes relate to those effects of movement activities that alter a movement's political environment in some way (Amenta et al. 2010). Cultural outcomes refer to changes in the attitudes, social norms and behaviors of the operating political actors (Earl 2004). Biographical outcomes refer to the impact of mobilization on the lives of participants in social movements (Giugni 2004b), as well as to the impacts on the life patterns of those targeted by social movements. ${ }^{3}$ Since these three types are not independent, despite the majority of the literature mistakenly treating them as such, I now turn to a discussion of six hypothetical processes via which a certain type of impact may help to bring about another type of impact (Figure 1). These hypothetical processes are by no means exhaustive, nor are they intended to demarcate inevitable sequences. Rather, they are components of the social change process that may occur following social movement protest. In certain cases, some processes may be missing, occur to different degrees, be mixed in varied combinations with other processes, or reverse and produce backlashes. In trying to transcend the single-outcome approach and embrace a broader perspective that provides insights into the role of contention for social change, we accept that an impact on one particular level can become a source of change at another.

\section{Political $\rightarrow$ cultural}

Policy outcomes prompted by social movements may act as, in the long term, sources for cultural change and result in substantial consequences for social behavior. Policy reforms play a critical role

Figure 1

Hypothetical processes

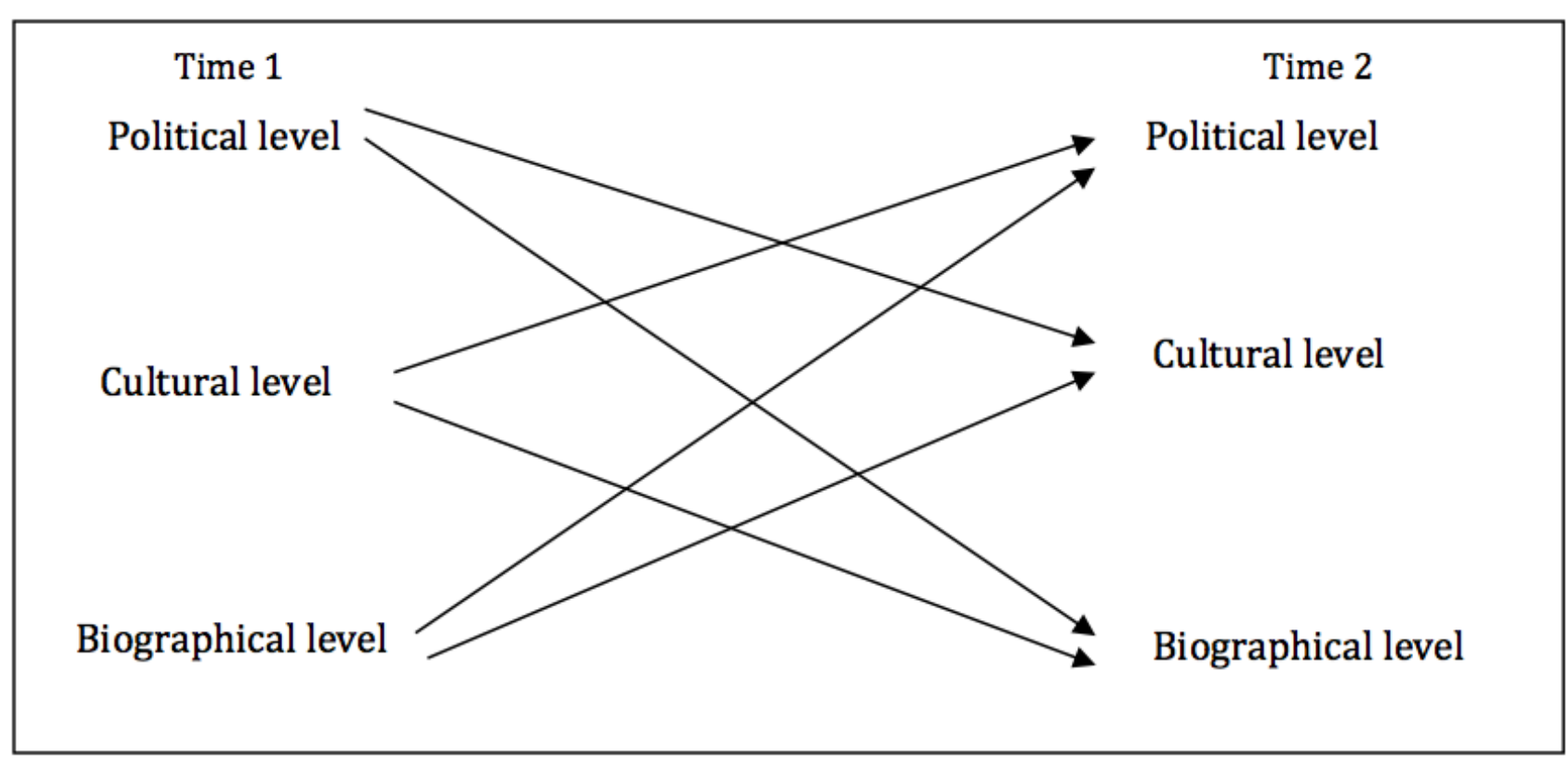


in changing values, opinions and beliefs and in defining individuals' behavior and identity in society. As Ronchon states in his important work on social movements and culture, policy change "speed[s] the dissemination of new values through the society by articulating norms of behavior and by sanctioning deviance" (1998: 31). In the long term, new policies become sources for attitudinal and behavioral change among challengers, their constituencies and the wider society. This is clearly the case for movements that address social welfare issues (Annetts 2009 et al.). Successes at the political level may favor identity recognition or the creation of new identities (Polletta and Jasper 2001; Amenta et al. 2010). This happens for example in recognition struggles, which, in fighting past discrimination and systematic exclusion from political and/or economic participation, are usually capable of strengthening the identity of the broader constituency. This was the case for the black civil rights movement in the USA (Polletta 1994; Ronchon 1998), and it can be easily observed if we look at ethnic mobilizations (Nagel 1995). Another illustrative example is that of the lesbian and gay movements that, having achieved political rights in many Western countries, have seen the negative perceptions of their identities changing perceptively (Bernstein 2005).

\section{Political $\rightarrow$ biographical}

In stimulating policy changes, social movements may have in the long term an impact on the lives of individuals. The expansion of structural access to resources such as education, voting, employment and medical care are fundamental to biographical changes (Annetts 2009 et al.). The labor movements in many countries have been able to achieve welfare reforms which have provided new resources and incentives to individuals (Amenta 2009). This is clearly a topical example, since it is well documented how far welfare reforms influence crucial life choices in the long term. For example, "[p]olicy shapes the identity of individuals and their conception of themselves as citizens who have obligations to participate and who deserve the protection of the state" (Ingram 2005: 207). Suzanne Mettler (2004), in her study of USA World War II veterans' actions, has demonstrated how the GI Bill of Rights affected their civic capacity and political involvement, raising the levels of education and skills of a whole generation of young men. For Mettler, the GI Bill had a long-term positive effect on political participation. The disability movement, with its results in terms of new legislations, has impacted on the everyday lives of disabled people, both in material and symbolic terms. They are no more "disabled" people, but rather rights-holders with a distinctive collective identity and dignity (Johnson 1999). Nancy Whittier (2016) has shown how the USA LGBT movement has brought about changes in the life-course of the LGBT broad community by promoting change in policies.

\section{Cultural $\rightarrow$ political}

In the long-term, cultural changes instigated by social movements can be translated into new public policies. Social movements have the ability to raise the salience and public profile of a particular set of issues by introducing changes in cultural values, opinions about and beliefs in social and political public discourses (Rochon and Mazmanian 1992; Rochon 1998; Meyer 1999, 2005; Polletta and Jasper 2001). Therefore, movements that win victories in terms of political culture, even when they have suffered immediate defeat on policy issues, can obtain public policy gains in the long term. Strong and clear changes in public opinion that are favorable to the movement's "message" provide the opportunity to significantly influence the process of public policy change, albeit indirectly. Elected officials, when they see prospects of electoral success and/or support for their mission, will follow changes in public discourses by placing a movement's "message" on the political agenda, coopting it for the governmental agenda and initiating a change in legislation (Baumgartner and Jones 1993; Burstein 1998, 1999; McAdam and Su 2002). For example, Kane (2003) finds that public opinion, which she sees as a form of cultural opportunity, has helped gay and lesbian movements in decriminalizing sodomy in American states. Looking at the history of the civil rights movement in the USA, for example, Rochon (1998) has underlined that racial segregation was first of all delegitimized at a cultural level, and only subsequently were rights obtained at a political level (57-68). The same trajectory can be noted in the impact of the abolitionist movement at the juncture of the eighteenth and nineteenth centuries, when the prohibition of the slave trade was only obtained at policy level after a change in public discourse and the views held in broader British society (d'Anjou 1996). David Meyer, in contrast, has underlined how the peace movement in the USA "won large changes in rhetoric and culture that subsequently translated into different policies" (1999: 196).

\section{Cultural $\rightarrow$ biographical}

Social movements' cultural consequences may engender biographical outcomes among former participants of the movement in the long term. A permanent feature of contentious collective action is the creation of broader counter-cultural networks, which set the stage for the formation of new communities with distinct cultures (Melucci 1989). A new community consciousness, group boundaries and opposition to an external enemy are constructed and established during contentious periods, changing personal biographies even after the movement ends (Polletta and Jasper 2001). Social movements which culturally influence the creation of new subcultures can then have a direct bearing on the individuals who are part of those communities (Earl 2004). Subcultures con- 
tinue to shape individuals' behavior in the long term: "they carry them into other social movements, influencing the later challenges" (Whittier 2004: 537). By adopting particular alternative lifestyles, former activists commit themselves to the cause of the social movement in the long term, which in turn increases individuals' availability for subsequent waves of protest. Furthermore, participation in these kinds of activities reinforces specific solidarities and identities, not only among former activists, but also among the movements' sympathizers. Cultural outcomes which help to establish new communities then facilitate the emergence of later mobilizations around the same or similar issues to those raised by previous movements (Meyer and Whittier 1994; Passy and Giugni 2000). Drawing on the European scene, Mario Diani (1997), for example, has described how social movement activists and sympathizers are able to affect new cultural norms and codes through the emergence of new networks following the mobilization phase (140-142). The integration of former activists within social circles such as the mass media, corporate cultural operators and the intelligentsia can foster the circulation of movement ideas, cultural practices and alternative lifestyles in which life-long commitment to the causes of the movement are maintained.

\section{Biographical $\rightarrow$ political}

A strong and long-term commitment by activists to a movement's cause may facilitate successive policy outcomes, and even changes in the institutions, when activists occupy state positions. Being close to and familiar with the policy-making process means that participants, or former participants, in the movement are, from a strategic point-of-view, best located to play a part in the interest-mediation arrangements that occur in conventional politics (Rochon and Mazmanian 1992). For example, when participants in the women's movement have entered mainstream political institutions they have been "able to structure programs that addressed women's interests, funding rape prevention training or child assault prevention training, special programming for elderly women within local Councils on Aging, or training in nontraditional careers as part of work training offered to women on public assistance" (Whittier 2004: 546-547; Banaszak 2010). Former activists who remain committed to the movement's cause can then be instrumental in relating the latter's goals to public agendas and policies, once they have access to policy making or become established in professional communities (Skrentny 2006; Kim et al. 2013). The processes of co-optation and the institutionalization of former committed activists do not, however, guarantee a-priori the full success of a social movement struggle, as favorable external circumstances also matter (Bosi 2016). An interesting example is that of the women's movement legacy in the US. Lee Ann Banaszak, in her work on the second wave of mobilization of the wom- en's movement in the 1960s, implicitly, among other multiple contributions, comes to our aid in describing how women's movement activists inside the state bureaucratic structures, in the period from the Kennedy to the Clinton administrations, were capable of "creating concrete policy changes that altered the social landscape in the United States" (2010: 4). Women's commitment to the feminist cause within the state "helped to write legislation, provided the rationale that convinced outsiders to support feminist legislation, provided information and resources to outsider women's movement organizations that helped them organize and mobilize in support of policy, and conducted lawsuits (in many cases against the government) to assure that existing policies were followed." (159).

\section{Biographical $\rightarrow$ cultural}

In the long term, the biographical impact of social movement activism may engender broad processes of change relevant to the earlier socio-cultural goals of the movement. Activists' cultural values and opinions are forged and mediated by their participation in social movements. Previous involvement in social movements may orient participants' political activities and affect their socio-cultural lifestyles, reshaping "the normative contours of the life-course" (McAdam 1999: 138) into broader processes of change. Alternative lifestyle patterns, stripped of their original political or counter-cultural content, are diffused and adapted through socialization processes across new cohorts as new life-course norms in the long term (McAdam 1999; Goldstone and McAdam 2001; Giugni 2004b). The biographical impact is an important means through which cultural transformations may be fostered in society at large. As Rochon writes, "the microfoundations of movement mobilization thus create new patterns of social thought and action, contributing to the breadth and pace of change in cultural values... ... The ripple effects of movement activism also have an impact on family, friends, and fellow members of a group" (1998: 162). Thus, the biographical consequences affect not only those who were active participants in a cycle of protest, but also "many casual participants" (Polletta and Jasper 2001: 296). As McAdam and his colleagues have expounded in various different publications (McAdam 1999; Van Dyke, McAdam and Wilhem 2000; Goldstone and McAdam 2001), the Sixties movements engendered a broad cultural change in the USA:

"first, activists in the political and countercultural movements of the period rejected normal life-course trajectories in favor of newer alternatives (e.g. cohabitation, childlessness, and an episodic work track); second, these alternatives to traditional patterns became embedded in a number of geographic and subcultural locations (most notably college campuses and self-consciously countercultural neighborhoods) that were the principal centers of the "1960s experience" and of New Left activism, thus leading upper- 
middle-class suburbs to embody the new alternatives through socialization processes; third, these alternative life-course patterns spread to increasingly heterogeneous strata of young Americans through processes of diffusion and adaptation, and were largely stripped of their original political or countercultural content to be experienced simply as new life-course norms" (Giugni 2008: 1591).

Shifting from a search for those spurious correlations which favor social movement outcomes (strategic tactics, the structure of political opportunities, organizational features, resource availability, public opinion), in this article I embrace the process-tracing mid-level approach, located between description and universal social laws (Stinchcombe 1995; Mahoney 2000, 2003; Hall 2003; George and Bennett 2005). Causal explanations are not abandoned, but rather foreseen through the identification of "steps in a causal process leading to the outcome of a given dependent variable of a particular case in a particular historical context" (George and Bennett 2005: 176). ${ }^{4}$ In this article, I embrace this research strategy and focus on some of the causal mechanisms, the combination of which has led in Northern Ireland to a process of social change experienced at the micro-level of Provisional IRA (henceforth PIRA) volunteers. ${ }^{5}$ In doing this I link the hypothesized cause, the British state responses at the policy level (policy outcome) toward the disruptive mobilization of the Catholic community in Northern Ireland and to the armed campaign of the PIRA, during the 1970s and 1980s, to my outcome of interest, the post-movement lives of PIRA volunteers (biographical outcome) (Bosi Forthcoming). The concatenation of three mechanisms: disruptive (the rise of costs imposed by one actor on another) (Pive and Cloward 1977); output responsiveness (the implementation of new legislation that has been adopted in response to social movements' mobilization) (Shumaker 1975); and cooptation ("incorporation of a previously excluded political actor in some center of power" (Tilly and Tarrow 2007: 215)) produced the political $\rightarrow$ biographical process of social change that this article aims to explain. A major advantage of using this approach is that it takes the contingent and endogenous aspects of social movements' interrelated effects into account while simultaneously allowing for the tracing of their trajectories over time. In doing so, it does not answer the question of why social change occurs but rather concentrates on how it does this.

\section{The Process of Social Change in the Biographical Outcomes of PIRA Volunteers}

At the end of the 1960s, political contention emerged in Northern Ireland over the demands of the civil rights movement (henceforth, CRM) to end the social and political exclusion of the Catholic community in the region (Purdie 1990). The Unionist establishment and the Loyalist counter-movement resisted such demands with harsh state repression and open, violent confrontation (DeFazio 2013). This socio-political crisis in the region opened up a space: first, for extreme communal violence during the summer of 1969, when many nationalists were burned out of their houses; second, for the British deployment of the army into the streets of Northern Ireland to restore law and order; third, for the emergence of the PIRA at the end of 1969, as an answer to Loyalist mobs and to the deterioration in relations between the British Army and the Catholic residents in the working-class neighborhoods (Bosi 2011). From 1971 the PIRA military campaign, aiming for British withdrawal from Northern Ireland and its unification with the Irish Republic, incorporated strategies such as bombings and armed attacks on security forces (from Northern Ireland and the Republic of Ireland), soldiers, commercial premises, militants from competing Republican armed groups, Loyalist paramilitaries, and civilians. The PIRA was the most violent actor in the Northern Ireland conflict (1969-1998), which also involved other Republican armed groups, Loyalist paramilitary groups, the Northern Ireland local police forces and the British Army.

The disruptiveness of the social protest at the first stage, and of the PIRA armed campaign afterwards, forced Westminster to intervene on ever-increasing occasions in Northern Ireland (disruptive mechanism) (Bosi 2016). Where initially it had put pressure on the Unionist establishment to concede a set of policy reforms to answer the Catholic mobilization, since it feared that the civil rights issue would damage its international legitimacy as the world's first liberal democracy, with the explosion of communal violence and the emergence of the PIRA armed campaign, it took progressively more and more direct initiative in the region, so as to re-establish its hegemonic control in there (Bosi 2016). In the aftermath of Bloody Sunday, when British soldiers killed 14 and wounded many Catholics at a demonstration in Derry, Westminster suspended the Stormont regime and introduced direct rule from London. The British state then complemented, with unequal discontinuous balance, counter-insurgency measures (Neumann 2003) with urban, social and economic development policy initiatives that were aimed at placating the mobilization of the Catholic community, at undermining support for the PIRA armed campaign in Catholic working class areas, and sought to stimulate Catholic participation in regional institutions. Its assumption was that once "British standards" were implemented in Northern Ireland by promoting public policies (Darby and Williamson 1978; Breen 2000; Osborne 2003), this would break the marginalization of the Catholic community and consequently they would be able to tackle the structural grievances that were seen as underpinning the violent conflict (Bean 2007; Whiting 2013).

Deprived Catholic working-class areas became, even during the neo-liberal years of Thatcher's government, of central interest for the British state, which 
started to implement Keynesian policies, from housing and planning to education and employment (output responsiveness mechanism). Catholic civil society in general, and the voluntary and community organizations more specifically, became increasingly subsidized, in terms of funding and resources. Through this combination of counter-insurgency measures with public policies the British state reshaped the context in which Republican politics were conducted in the following years and decades (Bosi forthcoming).

Confronted by heavy repression, the PIRA by the mid-1970s had reoriented itself at military level to a cell structure and at social and political level to some degree toward community development, with a view to maintaining a significant presence in the Catholic working-class areas (Darby 1986; Kevlihan 2013). However, in the early 1980s these "community organizations and political structures that had started out as agencies of revolutionary mobilization became [with the British socio-economy development policies] gatekeepers between the state and the nationalist community, as well as acting transmission belts for the Provisional movement" (Bean 2007: 6). This was an unintended outcome of the social and economic changes produced by British policies, but on the other hand this outcome suited the British interest in using the Provisionals as partners in the peace process and interlocutors who could assure the future stability of the new negotiated settlement (cooptation mechanism). Thus, when the British state progressively regained its power in the Catholic community in the ghetto areas, such power had to be shared with the PIRA, given its brokerage capacity between nationalist working-class areas and the British state.

Although far from publicly disregarding their former strategies, by the mid-1980s both the leadership of the PIRA and the British establishment came to realize that a military solution was not the winning option for either side (Bosi 2013). The majority of PIRA volunteers ${ }^{6}$ had been integrated into the institutional political process through a peace process that resulted in a new negotiated settlement in which the PIRA decided to take part together with the other political forces present in the Northern Ireland conflict (the British and Irish states and Northern Irish political parties). On August 31, 1994, the Provisional IRA announced a complete cessation of military activity allowing Sinn Féin, its political arm, to sit at the "peace talks in the following years, which eventually led to the Good Friday Agreement of April 12, 1998. As part of the Good Friday Agreement, reintegration programs for political prisoners were established, including training for former political prisoners, advocacy work, restorative justice projects, self-help initiatives, and youth and community work. PIRA volunteers refused to adopt the government agencies and other government-sponsored organizations and chose to use the welfare groups established by the PIRA in many areas throughout Northern Ireland (Shirlow and
McEvoy 2008; Dweyer and Maruna 2011), which were, however, subsidized by the British state.

The post-armed activists, whom I have met during my fieldwork, all say that in the last ten years or more they have experienced high rates of participation in day-to-day issues of distributional politics at local level (such as: interface work, youth work, reintegration to society efforts following incarceration; conflict transformation initiatives, community based anti-poverty and anti-racism work, truth recovery, developing sporting activities, participating in alternative Irish schools, notfor-profit employment, encouraging and managing funding proposals). Their involvement in the Republican movement, first as armed activists and then as political prisoners, has transformed most of the lives of my interviewees. One of them said: "I see my current occupation as a community worker with young people in my community as a continuation of my involvement in the Republican struggle" (Interview no. 15). By working within neighborhood community centers, which accommodate the social needs of local residents in areas with Catholic communities, they show that the political consciousness gained over more than thirty years of struggle within the Republican movement continues to motivate their full-time activism in the post-Agreement era. They exhibit a sense of obligation that in their words was similar to what brought them into the armed group at the beginning (Bosi 2012; Bosi and O'Dochartaigh 2016). As Interviewee no. 19 said:

\footnotetext{
"There is no question that the involvement in the Republican movement had an impact on me personally. I would not have been the person I am not being part of the movement. I would not have done what I am doing nowadays, [working in conflict transformation activities]"
}

Although they were involved in the armed struggle, my interviewees suggested that they have gained empowerment and agency (Bosi and O'Dochartaigh 2016). In the post-armed conflict situation they were not ready to leave what they had gained and they had the opportunity to carry this forward. Working in the neighborhood community centers has been viewed by my interviewees as a protraction of their involvement in the Republican struggle. They see their occupations nowadays as another form of participation while still feeling "helpful" and "determinant" for their own community (McEvoy and Shirlow 2009). These centers are seen to provide the transformative space to address the specific issues which impact their local communities and the broader Catholic community. Interviewee 20 pointed out: "I am nowadays a community worker, not affiliated with any political party. I am looking for investments in my community. I fight against poverty in my community" (Interview no. 20). The post-armed activists' involvement in community centers has fostered in most former armed activists social and political dispensation. Thus, where previously in the early stage such positions were taken with the awareness of the British involvement, but 
with the willingness to use these as possible resources in their struggles, in a later phase community activism has developed as a career path that has allowed some of my respondents to become central figures in their own communities and progressively disengage from political violence repertoires. Those former volunteers whom I have met indicate that the individual's empowerment within armed conflicts can be successfully carried over into post-conflict situations.

\section{Conclusions}

Scholars who have investigated biographical outcomes of social movements have noticed that, after their 'career', activists continue to espouse political attitudes close to those they embraced during their mobilization (Giugni 2004b), to show high levels of socio-political commitment and to pursue different lifestyles (jobs and structure of families) in concert with their beliefs. As such, the "standard interpretation" is valuable in understanding that social movement activism is important in post-movement lives. However, it tends to pay no attention to how states shape the social and political contexts within which activists conduct their lives. Thus, while the social movements' experience is likely to mold the former activists' post-movement lives, it is also true that the socio-political context plays a key role here. At an empirical level, this article's reading of the biographical outcomes of PIRA volunteers complements existing works on social movements' activists; but it also adds to it by demonstrating the mechanical effects of social change, how the British State's public policies reshaped the context in which Republican politics were conducted, through voluntary and community activism for community regeneration, and the nature of the change these policies caused, rather than assuming that post-movement life was the consequence of militant activism and the end point in itself.

Social movement scholars have until now spent most of their time trying to understand how social change causes social movements. In this article, I have reversed the causal order of the relationship and focused on how social movements generate broad processes of social change. In particular, I have recommended that an approach which looks at the interrelated effects of social movement outcomes provides a useful research strategy and offers a number of distinct advantages. Firstly, it identifies new opportunities for empirical investigations, allowing scholars to ask questions they might not otherwise ask, to identify social processes in possible explanations that would not otherwise be seen, and to find answers that would not otherwise be found were an outcome studied alone or separately. Secondly, it shifts away from the search for those invariant causal features that favor movement impacts toward a more dynamic analysis of the processes, leading to the interrelated effects of social movement outcomes by stating that social change is attained via various trajectory processes. Thirdly, it facilitates investigations that move beyond short-term impacts to long-term outcome processes and to the continuity of the challenger's legacy over time, thus setting the chronological dimension firmly back in social movement research. Fourthly, it allows us to recognize the complexity and multidimensionality of social change to a greater extent. One further and final advantage of this framework is that it provides a central opportunity for shifting the focus from single-outcome analysis-focusing on the narrow paths leading from social movement mobilization to success or failure-to broader processes of social change, which go beyond achieving goals, and also considers indirect and unintended outcomes that flow from movement activities.

This article is by no means exhaustive, and there is clearly much that can and should be done to substantiate this approach: e.g., using further empirical data to support and extend the arguments made, and possibly finding other potential trajectory processes and then, piece-by-piece, assembling formal hypotheses and rigorously testing them. In this sense, I do not suggest that the trajectories I have suggested here are the only ones; nor do I suggest that they are always present. The fact that we know that this is a worthy area of study, however, remains illustrative. What needs to be determined accurately is how interrelated effects are likely to take place. We must ask more complex questions about the extent and operation of interrelated effects of social movement outcomes. For example, under what conditions will each hypothetical trajectory process work? What are the limits of these hypothetical trajectory processes; that is, under what conditions do they fail to occur or are they reversed? Are there some which occur more often than others? Is the typology of a movement, right wing or left wing for example, a determinant for certain trajectories instead of others? How should we methodologically study such trajectories? When can an observed social change still be said to be a result of a trajectory process initiated by a social movement long since ended? What further research needs to be carried out in relation to the interrelated effects of social movement outcomes? The fair answer is that we do not know, and cannot know, until systematic empirical research is designed specifically to address these questions. At this early stage, this article underlines the lack of previous research on the interrelated effects of social movements, but does not purport to offer any definitive solutions. Most of the premises it offers are speculative and require extensive empirical scrutiny to ascertain their theoretical validity and consistency. The potential trajectory processes elaborated here may lead future research on the interrelated effects of social movements in more promising directions if such research is systematically conducted via a historical-sociological study that comparatively examines different movements over an extended period of time in one or more countries. 


\section{AcKnowledgments}

Social movements sometimes take time to achieve their goals, and social movement scholars are no different. I have worked on different parts of this article for almost fifteen years. The idea of looking at the interrelated effects of social movement outcomes has been a constant in my studies on how social movements matter, and I have presented such ideas at different conferences and workshops throughout these years. Donatella Della Porta, Marco Giugni, David Meyer, Nancy Whittier, Eduardo Romanos, Chris

\section{Notes}

1. Throughout this work, the terms "outcomes," "effects," "impacts" and "consequences" are used interchangeably.

2. A number of theoretical and methodological problems are connected with this area of study: the problems of goal adaptation; time reference and effect stability; unintended and perverse effects; and causal attribution (Bosi and Uba 2009; Giugni and Bosi 2011; Bosi, Giugni and Uba 2016).

3. The distinction between political, cultural and biographical levels is mainly for analytical purposes. This is particularly true in reference to the cultural and biographical level (Giugni and Bosi 2011).

4. The process-tracing approach entered the field of social movements' studies after the ground-breaking work by McAdam, Tarrow, and Tilly (2001; further Tilly and Tarrow 207). Social movement scholars have already fruitfully applied such approaches to the study of social movement outcomes (Andrews 2004; Kolb 2007; Bosi 2016).

\section{References}

Amenta, E. 2008. When Movements Matter: The Townsend Plan and the Rise of Social Security. Princeton, NJ: Princeton University Press.

Amenta, E., N. Caren, E. Chiarello, and Y. Su. 2010. "The Political Consequences of Social Movements." Annual Review of Sociology 36: 269-286. http://dx.doi. org/10.1146/annurev-soc-070308-120029

Andrews, K. 2004. Freedom is a Constant Struggle: The Mississippi Civil Rights Movement and Its Legacy. Chicago: University of Chicago Press.

Annetts, J., A. Law, W. McNeish and G. Mooney. 2009. Understanding Social Welfare Movements. Bristol: Policy Press.

Banaszak, L. 1996. Why Movements Succeed or Fail: Opportunity, Culture and the Struggle for Women Suffrage. Princeton: Princeton University Press. http://dx.doi.org/10.1515/9781400822072

Banaszak, L. 2010. The Women's Movement. Inside and Outside the State. Cambridge: Cambridge University Press

Baumgartner, F. and B. Jones. 1993. Agendas and Instability in American Politics. Chicago: Chicago University Press.

Bean, K. 2007. The New Politics of Sinn Féin. Liverpool: Liverpool University Press.

Bernstein, M. 2003. "Nothing Ventured, Nothing Gained? Conceptualizing Social Movement "Success" in the Lesbian and Gay Movement" Sociological Perspectives, 46 (3): 353-379. http://dx.doi.org/10.1525/sop.2003.46.3.353
Roots and Katrin Uba provided useful commentaries on this work at various stages. Particularly as I did not always follow the advice I was given, any failings remain solely mine, but my thanks go out to all of them for their extremely helpful comments and support. In its final version this article has benefitted from the generous support by the Spanish Ministry of Economy and Competitiveness [grant number CSO2013-41035-P].

5. By investigating the biographical outcomes of former armed activists, this article looks to address how political violence matters, which is an underdeveloped research question in the literature on political violence (Bosi and Giugni 2012).

6. PIRA volunteers have, by a large majority, followed the path of the leadership. A minority have followed four other paths: the path of continuing their armed struggle in dissident Republican groups such as the Real IRA, Óglaigh na hÉireann and the Continuity IRA; the path of joining other Republican groups, which nevertheless do not favor a return to armed struggle in the near future; the path of not choosing to join political prisoners groups or any political organization in their post-armed activist lives; and the path of involvement in organized crime.

Bernstein, M. 2005. "Liberalism and Social Movement Success: The Case of the United States Sodomy Statutes." Pp. 2-18 in E. Bernstein and L. Schaffner (eds.) Regulating Sex: The Politics of Intimacy and Identity. New York: Routledge.

Bernstein, M. and M. De la Cruz. 2009. "What Are You? Explaining Identity as a Goal of the Multiracial Hapa Movement." Social Problems 56(4): 722-745. http://dx.doi.org/10.1525/sp.2009.56.4.722

Bosi, L. 2011. "From "British Rights" to "British Out": the Northern Ireland's Civil Rights Movement Between the 1960s and Early 1970s", Pp. 125-138 in H. Kouki and E. Romanos (eds.) Protest Beyond Borders: Contentious Politics in Europe since 1945. Oxford: Berghahn.

Bosi, L. 2012. "Explaining Pathways to armed Activism in the Provisional IRA, 1969-1972". Social Science History, 36 (3): 347-390. http://dx.doi.org/10.1215/01455532-1595390 / http:// dx.doi.org/10.1017/S014555320001186X

Bosi, L. 2013. "Safe Territories and Political Violence: the Persistence and Disengagement of Violent Political Organizations" Nationalism and Ethnic Politics 19 (1): 80-101. http://dx.doi.org/10.1080/13537113.2013.761880

Bosi, L. 2016. "Incorporation and Democratisation: the long term process of Institutionalisation of the Northern Ireland Civil Rights Movement" Pp. in L. Bosi, M. Giugni and K. Uba (eds.) The Consequences of Social Movements. Cambridge: Cambridge University Press. http://dx.doi.org/10.1017/CBO9781316337790.014 http://dx.doi.org/10.1017/CBO9781316337790 
Bosi, L. Forthcoming. "Contextualizing the biographical outcomes of Provisional IRA former activists: a structureagency dynamic" in O. Fillieule and E. Neveau (eds.) Activists Forever? The Long-Term Impacts of Political Activism in Various Contexts. ECPR PRESS.

Bosi, L. and M. Giugni 2012. "Political Violence Outcomes: A Contentious Politics Approach" Mobilization 18 (1): 85-98.

Bosi, L., Marco. Giugni and K. Uba. 2016. The Consequences of Social Movements. Cambridge: Cambridge University Press.

Bosi, L. and N. O'Dochartaigh. 2016. "Armed activism as the enactment of a collective identity. The case of the Provisional IRA between 1969 and 1972." Unpublished paper presented at Goethe-Universitat Frankfurt.

Bosi, L. and K. Uba. 2009. "The Outcomes of Social Movement Action: An Introduction," Mobilization, 14 (4): 405-11.

Burstein, P. 1998. Discrimination, Jobs, and Politics. Chicago: University of Chicago Press.

Burstein, P. 1999. "Social Movements and Public Policy." Pp. 3-21 in Marco Giugni, Doug McAdam, and Charles Tilly (eds.), How Social Movements Matter. Minneapolis: University of Minnesota Press.

Breen. R. 'Class Inequality and Social Mobility in Northern Ireland, 1973 to 1996'. American Sociological Review 65(3) 2000.

Cassidy, K. 2005. "Organic Intellectuals and the Committed Community: Irish Republicanism and Sinn Féin in the North" Irish Political Studies 20 (3): 341-356. http://dx.doi.org/10.1080/07907180500359376

D’Anjou, L. 1996. Social Movements and Cultural Change: The First Abolition Campaign Revisited. New York: Aldine de Gruyter.

DaFazio, G. "The Radicalization of Contention in Northern Ireland, 1968-1972: A Relational Perspective," Mobilization 18:4, 475-496.

Darby, J. and A. Williamson. 1978. Violence and the Social Services in Northern Ireland. London: Heinemann Educational Books Ltd.

Diani, M. 1997. "Social Movements and Social Capital: A Network Perspective on Movement Outcomes." Mobilization 2 (2): 129-147.

Dwyer, C. and S. Maruna. 2011. "The role of self-help efforts in the reintegration of 'politically motivated' former prisoners: implications from the Northern Irish experience" Crime, Law and Social Change 55: 293-309. http:// dx.doi.org/10.1007/s10611-011-9284-7

Earl, J. 2004. "The Cultural Consequences of Social Movements" Pp. 508-530 in D. A. Snow, S. Soule, and $\mathrm{H}$. Kriesi (eds.) The Blackwell Companion to Social Movements. Oxford: Blackwell. http://dx.doi. org/10.1002/9780470999103.ch22

Giugni, M. 2004a. Social Protest and Policy Change. Oxford: Rowman and Littlefield Publishers.

Giugni, M. 2004b. "Personal and Biographical Consequences." Pp. 489-507 in D. A. Snow, S. Soule, and H. Kriesi (eds.) The Blackwell Companion to Social Movements. Oxford: Blackwell. http://dx.doi.org/10.1002/9780470999103.ch21

Giugni, M. 2008. "Political, Biographical, and Cultural Consequences of Social Movements", Sociology Compass 2 (5): 1582-1600. http://dx.doi.org/10.1111/j.17519020.2008.00152.x

Giugni, M. and L. Bosi. 2011. "The Impact of Protest Movements on the Establishment: Dimensions, Models, Approaches" in K. Fahlenbrach et al. (eds.) The 'Establishment' Responds. New York: Palgrave Macmillan.
Ingram, H. 2005. "Creating credible edibles: The alternative agriculture movement and passage of U.S. federal organic standards" Pp. in D. Meyer, V. Jenness and $\mathrm{H}$. Ingram (eds.) Routing the Opposition: Social Movements, Public Policy, and Democracy. Minneapolis: University of Minnesota Press.

Kane, M. D. 2003. "Social Movement Policy Success: Decriminalizing State Sodomy Laws, 1969-1998." Mobilization 8: 313-334.

Kim, S., P. Y. Chang, and G. Shin. 2013. "Past Activism, Party pressure, and Ideology: Explaining the Vote to Deploy Korean Troops to Iraq." Mobilization, 18(3): 243-266.

Kolb, F. 2007. Protest and Opportunities. Frankfurt/New York: Campus.

Johnson, R. A. 1999. "Mobilizing the Disabled" Pp. 24-45 in J. Freeman and V. Johnson (eds.) Waves of Protest: Social Movements Since the Sixties. Oxford: Rowman and Littlefield.

McAdam, D. and Y. Su. 2002. "The War at Home: Antiwar Protests and Congressional Voting, 1965 to 1973" American Sociological Review 67 (5): 696-721. http://dx.doi.org/10.2307/3088914

McAdam, D. 1994. 'Culture in Social Movements' Pp. 36-57 in New Social Movements, edited by E. Larana, H. Johnston and J. Gusfield. Philadelphia: Temple University Press.

McAdam, D. 1999. 'The Biographical Impact of Activism' Pp. 117-146 in How Social Movements Matter, edited by M. Giugni, D. McAdam and C. Tilly. Minneapolis: Minnesota University Press.

McAdam, D., J. Mc Carthy, and M. Zald. 1988. "Social Movements." Pp. 695-737 in N. Smelser (ed) Handbook of Sociology. Beverly Hills: Sage Publications.

McAdam, D., S. Tarrow and C. Tilly. 2001. Dynamics of Contention. Cambridge: Cambridge University Press. http://dx.doi.org/10.1017/CBO9780511805431

McEvoy, K. and P. Shirlow. 2009. "Re-imagining DDR. Excombatants, leadership and moral agency in conflict transformation" Theoretical Criminology 13 (1): 31-59. http://dx.doi.org/10.1177/1362480608100172

Melucci, A. 1989. Nomads of the Present: Social Movements and Individual Needs in Contemporary Society. Philadelphia: Temple University Press.

Meyer, D. 1999. 'How the Cold War Was Really Won: The Effects of the Antinuclear Movements of the 1980s' Pp. 182-203 in M. Giugni, D. McAdam and C. Tilly (eds.) How Social Movements Matter. Minneapolis: Minnesota University Press.

Meyer, D. 2005. 'Social Movements and Public Policy: Eggs, Chicken, and theory' Pp. 1-26 in D. Meyer, V. Jenness and $\mathrm{H}$. Ingram (eds.) Routing the Opposition: Social Movements, Public Policy, and Democracy. Minneapolis: University of Minnesota Press.

Meyer, D. 2006. "Claiming credit: Stories of movement influence as outcomes." Mobilization 11 (3): 201-18.

Meyer, D. 2007. The Politics of Protest: Social Movements in America. New York: Oxford.

Meyer, D. S. and N. Whittier. 1994. "Social Movement Spillover". Social Problems, 42(2): 277-297. h t t p: //dx.doi .org/10.2307/3096934 http://dx.doi.org/10.1525/sp.1994.41.2.03x0438v

Mettler, 2005. 'Policy Feedback Effects for Collective Action: Lessons from Veterans Programs' Pp. 211-235 in D. Meyer, V. Jenness and H. Ingram (eds.) Routing the Opposition: Social Movements, Public Policy, and Democracy. Minneapolis: University of Minnesota Press. 
Minkoff, D. 1997. "The Sequencing of Social Movements" American Sociological Review, 62: 779-99. http:// dx.doi.org/10.2307/2657360

Moore, K. 1999. "Political Protest and Institutional Change: Anti-Vietnam War Movement and American Science." Pp. 97-118 in M. Giugni, D. McAdam and C. Tilly (eds.) How Social Movements Matter. Minneapolis: Minnesota University Press.

Mueller, C. 1987. "Collective Consciousness, Identity Transformation, and the Rise of Women in Public Office in the United States." Pp. 89-108 in The Women's Movement in the United States and Western Europe: Consciousness, Political Opportunity, and Public Policy. Philadelphia: Temple University Press.

Nagel, J. 1995. "American Indian Ethnic Renewal: Politics and the Resurgence of Identity" American Sociological Review 60 (6): 947-965. http://dx.doi. org/10.2307/2096434

Neumann, P. 2003. British Strategy in the Northern Ireland Conflict, 1969-1998. Basingstoke: Palgrave Macmillan.

Passy, F. and M. Giugni. 2000. "Life-Spheres, Networks, and Sustained Participation in Social Movements: A Phenomenological Approach to Political Commitment" Sociological Forum 15: 117-144. http://dx.doi. org/10.1023/A:1007550321469

Olzak, S. and S.C. N. Uhrig. 2001. "The Ecology of Tactical Overlap." American Sociological Review 66: 694-717. http://dx.doi.org/10.2307/3088954

Osborne, R.D. 2003. "Progressing the Equality Agenda in Northern Ireland" Journal of Social Policy 32(3): 339360. http://dx.doi.org/10.1017/S0047279403007025

Piven, F. F. 2009. "How the Sixties movements put Obama over the top" The Sixties, 2 (1): 74-75.

LORENZO BOSI is Assistant Professor at the Scuola Normale Superiore. His academic work deals primarily with qualitative research on social movements and political violence. He has recently edited, together with Marco Giugni and Katrin Uba, "The Consequences of Social Movements" (Cambridge University Press).
Polletta, F. and J. Jasper, 2001, "Collective Identity and Social Movements", Annual Review of Sociology, 27: 283305. http://dx.doi.org/10.1146/annurev.soc.27.1.283

Polletta, F. 1994. "Strategy and Identity in 1960s Black Protest." Research in Social Movements Conflict and Change 17:85-114.

Purdie, B. 1990. Politics in the Street: the Origins of the Civil Rights Movement in Northern Ireland. Belfast: Blackstaff.

Rochon, T. 1998. Culture Moves: Ideas, Activism, and Changing Values. Princeton: Princeton University Press.

Rochon, T. R. and D. A. Mazmanian. 1993. "Social Movements and the Policy Process." Annals of the American Academy of Political and Social Science, 528: 75-87. http://dx.doi.org/10.1177/0002716293528001006

Ruane, J. and Jennifer T. 1996. The Dynamics of Conflict in Northern Ireland: Power Conflict and Emancipation. Cambridge: Cambridge University Press. http://dx.doi.org/10.1017/CBO9780511605598

Sztompka, P. 1995. The Sociology of Social Change. Oxford: Blackwell.

Whiting, M. 2013. Defying Moderation? The Transformation of Radical Irish Republicanism, 1969-2010. PhD dissertation. London: LSE.

Whittier, N. 2004. "The Consequences of Social Movements for Each Other." Pp. 531-551 in D. Snow, S. Soule, and H. Kriesi (eds.), The Blackwell Companion to Social Movements. Oxford: Blackwell. http://dx.doi.org/10.1002/9780470999103.ch23

Whittier, N. 2016. "Aggregate-Level Biographical Outcomes for Gay and Lesbian Movements" Pp. 130-156 in Lorenzo Bosi, Katrin Uba and Marco Giugni (eds.) The Consequences of Social Movements. Cambridge: Cambridge University Press. 